\title{
MILITANSI KADER PKS DALAM PEMENANGAN POLITIK PADA PEMILU LEGISLATIF 2009 DAN 2014 DI LAMPUNG
}

\author{
Triono $^{1}$,Dede Sri Kartini ${ }^{2}$, Affan Sulaeman ${ }^{3}$ \\ 1) Mahasiswa Program Doktor Ilmu Politik Pascasarjana FISIP \\ Universitas Padjadjaran, \\ dan Dosen pada Prodi Hubungan Internasional FISIP Universitas \\ Megou Pak Tulang Bawang \\ ${ }^{2,3)}$ Dosen Pascasarjana FISIP Universitas Padjadjaran \\ E-mail: \\ ${ }^{1)}$ triono.sr@gmail.com; ${ }^{2)}$ dedekartini@yahoo.com; ${ }^{3)}$ affansulaeman \\ @ gmail.com
}

\begin{abstract}
Abstrak
Keberadaan kader bagi partai politik merupakan suatu hal yang sangat vital dalam menjalankan roda organisasi partai dan kerja-kerja politik. Kompetisi antar partai politik dan tantangan politik yang semakin berat dalam setiap kontestasi politik pemilu maupun pemilukada menuntut partai politik untuk terus melakukan inovasi dan perumusan strategi-strategi politik dalam meraih kemenangan politik. Maka, menjadi suatu keniscayaan bahwa kader-kader partai yang memiliki loyalitas dan militan akan senantiasa dimaksimalkan peranannya dalam proses pemberdayaan sumber daya yang dimiliki oleh partai politik untuk pengembangan dan eksistensi partai politik dimasa depan.Tujuan utamanya adalahagar program dan kebijakan politik sebagai bagian dari produk politik partai politik dapat diterima oleh masyarakat melalui sosialisasi dan kampanye politik yang dilakukan oleh kader partai.
\end{abstract}

Kata Kunci: Pemilu, Partai Politik, Militansi Kader 
Triono,dkk: MILITANSI KADER PKS DALAM.......

\section{Pendahuluan}

Dinamika dan tantangan politik yang terus berkembang seringkali menuntut partai politik untuk terus berupaya malakukan inovasi-inovasi dalam hal perumusan strategi pemenangan politik. Hal ini karena perumusan dan pelaksanaan strategi dapat mempengaruhi sukses atau gagalnya strategi politik. ${ }^{1}$ Sebagai suatu sistem politik di alam demokrasi keberadaanpartaipolitikmerupakan sebuahkeharusandalamkehidupanpolitikmodernyangdemokratis. ${ }^{2}$

Karenanya tegaknya pilar sistem demokrasi dipengaruhi salah satunya oleh faktor adanya peran partai politik dalam mewarnai nilai-nilai kehidupan politik masyarakat dalam kehidupan berbangsa dan bernegara. Keberadaan partai politik menjadi sarana dan wadah aspirasi bagi masyarakat untuk dapat menyampaikan hak-hak politiknya melalui wakil-wakilnya yang duduk di lembaga eksekutif maupun legislatif.

Dalam upaya meraih kemenangan politik tersebut, menjadi sangatlah wajar manakala partai politik berlomba-lomba dalam memaksimalkan segala potensi dan sumber daya yang ada untuk meraih kemenangan politik dalam setiap kontestasi pemilu ataupun pemilukada. Diantara faktor yang menjadi prioritas utama dalam pengembangan sumber daya partai adalah melalui rekrutmen politik kader-kader partai yang memiliki loyalitas dan militansi tinggi untuk menggerakan mesin partai dan melakukan kerja-kerja politikdalam upaya menjaga eksistensi partai politik dan kemenangan-kemenangan politik.Hal ini seperti yang

\footnotetext{
${ }^{1}$ Toni Pito Andrianus, dkk., Mengenal Teori-Teori Politik dari Sistem Politik sampai Korupsi, (Bandung: Penerbit Nusantara, 2006), h. 196.

${ }^{2}$ Ichlasul

Amal,Teori-teoriMutahir PartaiPolitik,(Yogyakarta:PTTiaraWacana, 2007).
} 


\section{Triono,dkk: MILITANSI KADER PKS DALAM.......}

disebutkan Eastondalamteorisistemnyabahwapartaipolitik adalahsalahsaturegulatortuntutan di setiap massanya. ${ }^{3}$

Dalam perkembangan demokrasi dan politik di Indonesia, era reformasi di tahun 1998 menjadi awal yang baik dalam pertumbuhan alam demokrasi yang sehat dan terbuka. Kebebasan dalam mendirikan partai politik dan menyampaikan aspirasi publik telah di lindungi oleh negara berdasarkan perundangundangan. Era reformasi ini juga menjadi titik tolak lahirnya partai-partai baru dalam pemilu 1999, seperti disebutkan oleh Husein peneliti Perludem bahwa era reformasi ditandai dengan banyaknya partai politik yang lahir dan menjadi kontestan dalam pemilu di Indonesia. Tercatat di era reformasi muncul 141 partai politik baru di Indonesia. ${ }^{4}$ Dan Salah satu partai baru yang lahir di era reformasi tersebut adalah Partai Keadilan (PK). Menurut Rahmat sebagai partai pendatang baru, PK telah memberikan nuansa politik yang berbeda dalam sistem kepartaian di Indonesia, partai ini lahir dari gerakan kalangan anak muda dan aktivisaktivis kampus. ${ }^{5}$

Dalam perjalanannya PK menunjukkan jati dirinya sebagai partai yang membangun proses demokratisasi di internal partainya. Jika menilik sejarah dan platform kebijakan partai, Partai Keadilan relatif memiliki karakteristik yang hampir sama dengan Partai-Partai Keadilan yang ada di dunia seperti: Adalet Ve Kalkinma Partisi (AKP) di Turki, Partai FJP di Mesir, Partai An Nahdhah di Tunisia, Partai PAS di Malaysia, Partai Front Islamic du Salut (FIS) di Al Jazair, Partai Hamas di Palestina, dan

${ }^{3}$ David Easton, A Framework for Political Analysis, (Toronto: The Prentice Hall of Canada, 1965), h. 122-123.

${ }^{4}$ Harun Husein, Pemilu Indonesia: Fakta, Angka, Analisis, dan Studi Banding,(Jakarta: Perludem, 2014), h. 125.

${ }^{5}$ M. ImdadunRahmat, Ideologi Politik PKS; Dari Masjid Kampus ke Gedung Parlemen, (Yogyakarta: LkiS, 2008), h. 7.

Jurnal TAPIs Vol. 14 No.02 Juli-Desember 2018 
Triono,dkk: MILITANSI KADER PKS DALAM.......

di negara-negara Timur Tengah lainnya. Kesamaan tersebut dapat dilihat dari sumber ideologi politik partai sebagai ruh perjuangan partai dan gerak perjuangan politiknya.

PKS hadir dengan memposisikan diri sebagai partai politik Islam sebagaimana yang termaktub dalam AD/ART PKS, Amir menyebutkan bahwa karakteristik yang melekat pada parpol Islam adalah penggunaan simbol-simbol Islam dan basis massa Islam dalam pergerakannnya. PKS menggunakan Islam sebagai ideologi partai dengan mengusung nilai-nilai dakwah dalam pergerakannya. ${ }^{6}$ Dinamika dan peristiwa yang terjadi di internal PKS menjadi hal yang menarik untuk dikaji khususnya dalam dinamika kehidupan demokrasi politik di Indonesia. Eksistensi dan elektabilitas PKS sebagai entitas politik benar-benar di uji dari berbagai isu-isu dan peristiwa yang terjadi. Peristiwa politik tersebut tentu sebagai bagian ujian bagi soliditas kader-kader PKS dan keberlangsungan partai dalam kancah politik di Indonesia.

Jika melihat visi misi yang di emban PKS, dapat dilihat bahwa agenda besar sebagai grand strategy yang diperjuangkan PKS adalah mewujudkan masyarakat Indonesia yang madani. Madani sebagai representasi dari kondisi kultural bangsa Indonesia yang kaya akan suku, agama, ras dan antar bangsa (SARA). Konsepsi politik Islam yang dikembangkan PKS menjadi alat perjuangan sekaligus solusi dalam kehidupan berbangsa dan bernegara. Prinsip-prinsip inilah yang menurut hemat penulismenunjukan bahwa PKS memposisikan dirinya sebagai bagian dari pemberi solusi di Indonesia dalam menjaga persaudaraan yang adil di kalangan umat manusia, jauh dari bentuk rasialisme atau fanatisme kesukuan, ras dan etnisitas.

${ }^{6}$ Zainal AbdidinAmir, Peta Politik Islam Pasca Soeharto, (Jakarta: LP3ES, 2003). 


\section{Triono,dkk: MILITANSI KADER PKS DALAM.......}

Hadirnya kader-kader PKS dalam kepemimpinan kepala daerah menjadi salah satu bukti bahwa PKS memiliki positioning di masyarakat. Hubungan dengan partai-partai lain pun diperlihatkan PKS dengan bekerjasama dalam bentuk koalisi politik untuk memajukan suatu daerah. PKS selalu memiliki nilai tawar dalam setiap momen pemilukada dan Pilpres di Indonesia. Realita ini tentu saja memberikan gambaran dan ada suatu hal yang menarik dari PKS dalam pengelolaan manajemen partai dan strategi pengelolaan political marketing di internal partainya. Polemik dan peristiwa politik yang menimpa PKS mampu dikelola dengan baik yang justru dapat menjadikan PKS kian diperhitungkan kredibilitasnya oleh partai-partai lain.

Fenomena ini menjadi bagian dari dinamika yang berkembang di internal PKS, dimana menurut Herdiansah hal ini menunjukan soliditas internal partai dan kemandirian kader-kader PKS menjadi suatu system of solidarity dalam memperkokoh basis institusi partai dan gerakannya. ${ }^{7}$ Hadirnya PKS dalam percaturan politik Indonesia yang mengusung Islam sebagai dasar ideologi partai menjadi corak baru dalam perkembangan politik Indonesia dan menjadi market politik dikalangan anak muda.

Dalam konteks Lampung, PKS hadir sejak tahun 1998 sebagai bagian dari entitas politik di Provinsi Lampung, keberadaan PKS kerap memiliki posisi tawar dalam setiap gelaran politik di Lampung. Tercatat sejak pemilu 1999 sampai dengan 2014 perolehan suara PKS Lampung mengalami kenaikan. Pada pemilu legislatif 2009 PKS Lampung untuk tingkat DPRD Provinsi Lampung memperoleh suara sebanyak 302.835 dengan perolehan 7 kursi di parlemen daerah dan pada pemilu legislatif 2014 perolehan suara PKS mencapai 391.266 dan mendudukan

${ }^{7}$ Ari Ganjar Herdiansah, Rasionalitas PKS; Berdemokrasi ala Tarbiyah, (Bandung: Unpad Press, 2016).

Jurnal TAPIs Vol. 14 No.02 Juli-Desember 2018 


\section{Triono,dkk: MILITANSI KADER PKS DALAM.......}

kadernya di DPRD Lampung sebanyak 8 orang. ${ }^{8}$ Tulisan artikel ini mengkaji tentang dinamika politik PKS dan peranan militansi kader PKS dalampemenangan pemilu legislatif 2009 dan 2014di Provinsi Lampung.

\section{Metode}

Dalam kajian ilmu politik, menurut Marsh dan Stoker ${ }^{9}$ metode kualitatif telah memainkan peran utama mulai dari penelitian yang bersifat individu maupun kelompok dalam kancah politik formal hingga sikap dan perilaku masyarakat diluarnya seperti pada perilaku memilih. Oleh karenanya, data-data serta argumentasi yang dibangun dalam penelitian ini menggunakan studi kualitatif, yakni dengan mengumpulkan berbagai sumber referensi ilmiah dari sumber primer dengan wawancara kepada informan penelitian dan sumber sekunder melalui penelusuran tulisan terkait seperti jurnal, paper, dan berita media massa tentang model political marketing partai politik.

Penulis menggunakan teknik analisis data yang terdiri dan tiga alur kegiatan yang terjadi secara bersamaan, yang meliputi kegiatan reduksi data, penyajian data dan penarikan kesimpulan atau verifikasi. ${ }^{10}$ Analisis data dilakukan dengan analisis deskriptif dengan menelaah dinamika politikPKS dan peran kader dalam pemenangan politik pada pada pemilu legislatif 2009 dan 2014 di Lampung.

\footnotetext{
${ }^{8}$ Sekretariat Komisi Pemilihan Umum (KPU) Provinsi Lampung, 2017.

${ }^{9}$ David Marsh,dan Gerry Stoker,Teori dan Metode dalam Ilmu Politik, (Bandung: Nusa Media, 2011), h. 240.

${ }^{10}$ M. B, Miles \& A. M Huberman, Qualitative Data Analysis, A Sourcebook of New Methods, (London, New Delhi: Sage Publications, Beverly Hills, 1992), h. 16-21.
} 
Triono,dkk: MILITANSI KADER PKS DALAM.......

\section{Pembahasan}

Dalam AD/ART PKS disebutkan bahwa Partai Keadilan (PK) didirikan di Jakarta pada hari Senin, tanggal 26 Rabi'ul Awwal 1419 H bertepatan dengan 20 Juni 1998. Dalam perkembangannya dikarenakan Partai Keadilan yang pada pemilu 1999 tidak memenuhi electoral threshold untuk menjadi peserta pemilu 2004. Maka pada hari Sabtu, tanggal 09 Jumadil 'Ula $1423 \mathrm{H}$ bertepatan dengan 20 April 2002 di deklarasikan Partai Keadilan Sejahtera (PKS) sebagai kelanjutan dari perjuangan Partai Keadilan (PK). Dalam pergerakannya, PKSmerupakan transformasi dari gerakan dakwah kampus, partai ini didirikan oleh para aktivis muslim Indonesia, khususnya para intelektual kampus yang mempunyai latar belakang sebagai aktivis atau mantan aktivis mahasiswa, baik perguruan tinggi dalam negeri maupun luar negeri.

Secara jelas ideologi PKSdapat dilihat pada arah platform kebijakan partai yang mengatakan bahwa dari prediksi akan menguatkannya kesadaran politik masyarakat dan seiring dengan penguatan ideologisasi dalam tubuh partai politik, perlu kiranya terdapat kebijakan dasar dalam mengantisipasi kemungkinan menguatnya konflik di kalangan aktivis partai, kebijakan dasar tersebut adalah: (1) Memproyeksikan Islam sebagai sebuah ideologi umat yang landasan perjuangan politik menuju masyarakat sejahtera lahir dan batin. (2) Menjadikan ideologi Islam sebagai ruh perjuangan pembebasan manusia dari penghambatan antara sesama manusia menuju penghambatan hanya kepada Allah SWT, pembebasan manusia dari kafakiran ideologi rekaan manusia menuju keadilan Islam dan mengantarkan manusia kepada kebahagiaan dan ketenangan hidup. (3) Operasionalisasi ideologi Islam dan cita-cita politiknya di atas tiga prinsip, yaitu:Pertama, Kemenyeluruhan dan finalitas sistem Islam. Kedua, Otoritas syariah dan bersumber dari Al-

Jurnal TAPIs Vol. 14 No.02 Juli-Desember 2018 


\section{Triono,dkk: MILITANSI KADER PKS DALAM.......}

Qur'an dan al-Sunnah dan Ijtihad (proses kreativitas berpikir). Ketiga, kesesuaian aplikasi sistem dan solusi Islam dengan setiap zaman dan tempat. ${ }^{11}$ Menurut Abu Ridha akar ideologi tersebut sekaligus menjadi unsur utama komponen strategi dalam perjuangan mewujudkan cita-cita politik PKS baik yang bersifat universal maupun khusus. ${ }^{12}$

Langkah politik yang dilakukan PKSdengan pertimbangan di atas menerapkan Islam secara keseluruhan adalah dengan pembangunan sistem, yaitu dengan memperjuangkan konsepsikonsepsi Islam dalam sistem kemasyarakatan dan kenegaraan. Pembangunan komunikasi politik yang dipandang perlu, agar orang lain mau berpartisipasi dengan penyadaran umum terhadap pentingnya sistem politik Islami sebagai solusi terhadap persoalan bangsa dan negara, kemudian mengokohkan kredibilitas dan efektivitas komunikasi antara partai politik dan masyarakat.

Menurut Damanik ${ }^{13}$ PKS memiliki 7 (tujuh) karakter yang sama seperti PK yaitu: Pertama, Moralis, PKS berupaya menjadikan komitmen moral sebagai ciri seluruh perilaku individu dan politiknya. PKSberusaha menampilkan sisi moralis yang bersumber dari nilai-nilai Islam ini sebagai basis dan ketaladanan. Kedua, Profesionalitas, bercirikan pada penguasaan detail masalah yang mengantarkan partai pada kebijakankebijakan yang tepat dan bertanggungjawab atas berbagai masalah yang dihadapi, baik dalam bidang sosial, politik, ekonomi maupun budaya. Pembentukan pribadi dengan

\footnotetext{
${ }^{11}$ www.hidayah.com/pks siapdiakses pada 27/7/2017.

${ }^{12}$ Abu Ridha, Politik Tegak Lurus PKS; Jalan Mencapai Kemenangan yang Bermartabat dan Penuh Berkah, (Solo: Era Adicitra Intermedia, 2018), h. 315 .

${ }^{13}$ Ali Said Damanik, Fenomena Partai Keadilan; Transformasi 20 Tahun Gerakan Tarbiyah di Indonesia, (Jakarta: Teraju, 2002), h. 239-256.
}

Jurnal TAPIs Vol. 14 No.02 Juli-Desember 2018 
Triono,dkk: MILITANSI KADER PKS DALAM.......

memperhatikan intelektualitas, sikap kritis dan sensitivitas mendapatkan perhatian yang penting dalam perhatian partai ini.

Ketiga, Patriotik, kehidupan berpartai adalah bentuk kehidupan perjuangan. Sedangkan partai merupakan salah satu wajihahdakwah Islam yang bertujuan menegakkan nilai-nilai Islam. Karena itu, bagi kader, berjuang di jalan Allah adalah sebuah kewajiban yang harus dijalani demi tegaknya wibawa umat dan kemanusian umumnya. Keempat, Moderat, pemikiran, pandangan dan sikap-sikap modernisasi, berimbang dan pertengahan serta saling melengkapi bagi manusia dan kehidupan merupakan sikap yang obyektif dan selaras dengan tata alamiah.

Kelima, Demokrat, prinsip demokrat adalah penerimaannya terhadap nilai-nilai universal demokrasi sebagai bentuk pengakuan manusia dalam tanggungjawabnya sebagai khalifatullah. Salah satu substansinya yaitu partisipasi rakyat dalam penyelenggaraan kekuasaan tidak bertentangan dengan nilai-nilai syara' (musyawarah). Keenam, reformis, PKSmenempatkan posisi sebagai reformis serta berusaha konsisten menjauhi segala bentuk karakter dan sifat-sifat yang menimbulkan kerusakan. Dan Ketujuh, Independen, dengan merujuk pada konteks dakwah seperti yang diucapkan oleh panglima perang Rabi'ibin Amir, yaitu membebaskan penghambaan sesama manusia menuju penghambaan kepada Allah semata, dari kesempitan menuju keluasan dunia-akhirat, serta dari tirani agama menuju tirani Islam.

\section{Karakteristik PKS sebagai Partai Islam}

Karakteristik PKS sebagai partai kader menunjukkan pola strategi politik yang di jalankan berjalan dengan masif hampir di semua infrastruktur partai dari tingkat pusat sampai ranting. Istilah partai konservatif kerap melekat di PKS karena prinsip 
Triono,dkk: MILITANSI KADER PKS DALAM.......

"sami'na wa atho'na" di tubuh kader berjalan dengan kuat. Secaraideologis, PKS diuntungkan dengan menjadikan Islam sebagai asas partainya meskipun hal ini terkadang masih mendapat penilaian negatif dari masyarakat, kesan eklusif masih menjadi pekerjaan rumah yang perlu diselesaikan oleh PKS. Fenomena politik Islam yang diwakili oleh PKS dengan beberapa partai-partai yang memiliki basis massa Islam menjadi cara dan jalur dalam mendapatkan suara dan kekuasaan untuk kepentingan masyarakat.

Hertanto menyebutkan kesan eksklusif yang dimiliki PKS kerap menjadi ganjalan bagi PKS untuk lebih membuka diri dengan masyarakat luas, hal inilah barangkali diperlukan strategi komunikasi politik lebih baik lagi yang perlu dilakukan oleh PKS. ${ }^{14}$ Akademisi Unila Suwondo menambahkan bahwa jika PKS ingin berkembang menjadi partai besar, PKS harus berani merubah image ekslusif yang selama ini dirasakan oleh sebagian masyarakat yang dirasa masih dilakukan oleh kader-kader PKS. ${ }^{15}$ PKS menurut Suwondo perlu merubah jati dirinya dari sikap ekslusif menjadi partai terbuka terhadap semua lapisan masyarakat. Hal ini bertujuan untuk membangun jaringan yang lebih luas dalam upaya meningkatkan perolehan suara di pemilu. Dalam tataran elit-elit politik PKS barangkali sikap eklusif ini bisa dihilangkan dan di normalisasi, namun dalam tataran kaderkader di bawah masih banyak memperlihatkan praktek-praktek yang terkesan menjaga jarak dengan masyarakat di lingkungannya karena bukan merupakan bagian dari komunitasnya.

\footnotetext{
${ }^{14}$ Wawancara dengan Hertanto (Akademisi/Pengamat Politik Universitas Lampung, 30 Agustus 2017, di UNILA Bandarlampung).

${ }^{15}$ Wawancara dengan Suwondo (Akademisi/Pengamat Politik Universitas Lampung, 29 Agustus 2017, di UNILA Bandarlampung).

Jurnal TAPIs Vol. 14 No.02 Juli-Desember 2018 
Triono,dkk: MILITANSI KADER PKS DALAM.......

Hasil wawancara penulis dengan salah seorang pengurus DPW PKS Lampung ${ }^{16}$ dijelaskan bahwa persoalan ini memang di akui internal PKS dimana masih menjadi pekerjaan rumah bagi PKS, secara struktur sebenarnya PKS selalu memberikan arahan dan pembinaan kepada kader-kadernya untuk lebih terbuka dan bersosialisasi dengan masyarakat tanpa memandang golongan atau kelompok tertentu, sebab prinsip yang harus dikedepankan adalah Islam rahmatan lil 'alamin. Berbagai upaya yang telah dilakukan untuk menghilangkan image eksklusif PKS adalah dengan mengadakan kegiatan-kegiatan yang melibatkan kader dan masyarakat untuk saling berinteraksi. Tujuannya adalah menjelaskan dan menunjukan kepada masyarakat bahwa PKS bukan partai milik golongan tertentu saja namun milik semua lapisan masyarakat Indonesia. Hal ini penting sebagai upaya membangun basis konstituen dan menempatkan diri sebagai partai terbuka kepada semua golongan.

Prinsip-prinisip universal ini setidaknya dapat dilihat dari hubungan antara garis ideologi dengan model jaringan sosial yang dilakukan oleh PKS. Pembatasan nilai-nilai kebijakan dasar yang dijabarkan dalam 10 (sepuluh) landasan gerak juang diantaranya adalah al ishlah (reformatif). Sementara jaringan sosial ditegaskan dalam prinsip al numuw wa al tathawwur (tumbuh dan berkembang) tidak melahirkan stagnasi dan kehilangan kreativitas. Prinsip lainnya adalah alawlawiyat wa al mashlahah (prioritas dalam kemanfaatan) yang lebih merefleksikan kebutuhan strategi dan taktik perjuangan yang melekatkkan kepentingan ummat di atas kepentingan individu dan kelompok.

\footnotetext{
${ }^{16}$ Wawancara dengan Akhmadi Sumaryanto (Pengurus DPW PKS Lampung/Anggota DPRD Lampung Periode 2014-2019, 28 Agustus 2017, di Ruang Fraksi PKS DPRD Lampung).
} 
Triono,dkk: MILITANSI KADER PKS DALAM.......

Berkenaan dengan hal ini, salah seorang informan yang penulis wawancarai menyatakan bahwa: "PKS sejauh yang saya perhatikan selama ini mampu menunjukan jati dirinya sebagai partai yang peduli dan cepat tanggap terhadap isu-isu keummatan baik sekala domestik maupun global. Secara tidak langsung ini memberikan nilai positif bagi PKS dalam pengelolaan pencitraan di ranah publik. Hal lainnya adalah kader-kader PKS yang menjadi pejabat publik lebih terbuka dan supel dalam melakukan komunikasi publik...",17

Membandingkan PKS dengan partai lain yang secara lahir dan modal politik lebih besar tentu tidak akan sebanding. Hal inilah yang menjadikan PKS memilih karakter sebagai partai yang responsif terhadap isu-isu yang berkembang di masyarakat. Keterbatasan modal ekonomi menjadikan PKS menuntut diri untuk mengelola pola strategi-strategi politik lain yang lebih mudah dan murah untuk dijalankan. Tema-tema kampanye politik yang langsung bersentuhan dengan kebutuhan masyarakat menjadi poin bagi PKS untuk lebih berkreasi dan berkarya dalam menciptakan produk-produk politiknya.

Inilah barangkali yang menjadi catatan penting dari penulis, mengapa PKS masih tetap survive sejak pemilu 1999 sampai pemilu 2014, perolehan suara yang relatif stabil dan merata di seluruh Indonesia jika dibanding dengan partai-partai berbasis massa Islam lainnya. Penulis melihat PKS masih mampu menunjukkan keberadaan dirinya yang memiliki daya tahan dan manajerial partai yang relatif lebih baik, PKS mampu meyakinkan kepada publik bahwa PKS adalah partai yang akan terus ada dalam alam demokrasi Indonesia. Perolehan suara Partai Keadilan (PK) dalam Pemilu 1999 yang memperoleh suara 1.436.565

\footnotetext{
${ }^{17}$ Wawancara dengan Saprudin (Wartawan Tribun Lampung, 25 Juli 2017, di kantor Tribun Lampung Bandarlampung).
}

Jurnal TAPIs Vol. 14 No.02 Juli-Desember 2018 
Triono,dkk: MILITANSI KADER PKS DALAM.......

(1,39\%) dengan perolehan kursi di parlemen sebanyak 7 kursi membuat PK berbenah diri dengan melakukan metamorfosa politik menjadi PKS dalam pemilu 2004. Dalam konteks Lampung pun, di pemilu 1999 PKS baru mampu menempatkan 1 orang kadernya yang duduk sebagai anggota DPRD Lampung. Dorongan untuk tetap ada sebagai partai peserta pemilu dan survive dalam pemilu 2014 menjadi motivasi semangat PKS untuk terus melahirkan strategi-strategi politik yang lebih baik hingga pemilu selanjutnya, alhasil kini PKS telah memiliki 8 kursi di DPRD Lampung.

Menurut Ade Utami Ibnu, ${ }^{18}$ Partai Keadilan atau PKS (sekarang) selain faktor kaderisasi yang membuat PKS tetap eksis itu adalah karena adanya sistem partai yang berjalan dengan baik. Sistem ini artinya bahwa partai politik sebagai sebuah organisasi itu betul-betul dari tahun ke tahun sejak awal berdirinya itu dibuat dengan penataan sistem organisasi yang modern. Jadi betul-betul dihidupkan yang namanya organisasi, yang namanya PKS sebagai sebuah organisasi betul-betul dikelola dengan tata kelola yang modern dan itu yang membuat siapapun yang diberikan amanah untuk menjadi pimpinan-pimpinan partai atau pengurus partai itu sudah mekanistis, sekarang sistemnya sudah berjalan tidak ada kekhawatiran bahwa ketika ganti orang kemudian perjuangannya berubah atau ganti tokoh kemudian perjuangannya berubah tidak, tetapi siapapun yang menjadi pengurus di PKS itu dia mengikuti sistem yang sudah dibangun dan sistem itu sendiri atau organisasinya sendiri juga dibangun untuk terus bertumbuh.

Perubahan PK menjadi PKS menjadi tantangan tersendiri bagi kader-kadernya, hal ini dikarenakan perubahan orientasi dari

\footnotetext{
${ }^{18}$ Wawancara dengan Ade Utami Ibnu (Sekretaris DPW PKS Lampung/Anggota DPRD Lampung Periode 2014-2019, 26 Juli 2017, di Kantor DPW PKS Lampung).
}

Jurnal TAPIs Vol. 14 No.02 Juli-Desember 2018 
gerakan dakwah yang mencoba peruntungan melalui partai agama yang konservatif belum mampu menghasilkan perolehan suara yang tinggi. Hal ini seperti dijelaskan oleh Syarief Makhya yang menyatakan bahwa, kecenderungan politik di Indonesia memperlihatkan bahwa partai kader itu cenderung lambat dalam meningkatkan elektabilitasnya dalam perolehan suara di pemilu, hal ini dikarenakan, partai kader basis massanya relatif terbatas hanya pada tataran kader. Oleh karenanya bagi partai kader diperlukan upaya-upaya sistematis dalam perencanaan programprogram politiknya yang mampu meningkatkan perolehan suara pemilu dan elektabilitasnya di masyarakat. ${ }^{19}$

\section{Proses Kaderisasi dan Tarbiyah ala PKS}

Keberadaan kader dalam suatu organisasi merupakan jantungnya dari suatu pergerakan dan perjuangan. Kader menjadi seperti ujung tombak dalam sukses atau tidaknya perjalanan suatu organisasi. Maka menjadi hal yang penting manakala proses kaderisasi dalam suatu organisasi menjadi fokus perhatian utama dalam regenerasi suatu kepemimpinan organisasi seperti partai politik. Sebagai partai yang menyatakan dirinya partai kader, PKS memiliki sistem kaderisasi yang baik mulai dari mekanisme rekrutmen, pembinaan, dan pemberdayaan kader-kader PKS di ranah publik.Mekanisme sistem rekrutmen kader di PKS terdiri dari dua pola rekrutmen yaitu: rekrutmen fardiyah dan rekrutmen jama'i.

Rahmat $^{20}$ menjelaskan proses rekrutmen fardiah (pribadi) ini dilakukan oleh anggota tarbiyah terhadap satu atau dua orang dengan pendekatan pribadi atas inisiatif sendiri atau rekomendasi

\footnotetext{
${ }^{19}$ Wawancara dengan Syarief Makhya (Akademisi/Pengamat Politik Universitas Lampung, 30 Agustus 2017, di UNILA Bandarlampung).

${ }^{20}$ M. ImdadunRahmat, Ideologi Politik PKS; Dari Masjid Kampus ke Gedung Parlemen, (Yogyakarta: LkiS, 2008).
}

Jurnal TAPIs Vol. 14 No.02 Juli-Desember 2018 


\section{Triono,dkk: MILITANSI KADER PKS DALAM.......}

murabbi, dalam proses ini sering juga disebut dengan istilah dakwah fardiah. Pada proses rekrutmen ini dilakukan dengan cara seseorang anggota tarbiyah mencari calon peserta tarbiyah, dimana calon tersebut kemudian dikondisikan melalui tahaptahapan, antara lain: ta'aruf (perkenalan dan pendekatan, ikhtiar (upaya memengaruhi si calon), dan taqarrub (mendekatkan atau menghubungkan si calon dengan komunitas tarbiyah). Hasil dari upaya pemantauan ini kemudian dilaporkan, dibicarakan, dan dianalisis dalam forum halaqoh berdasarkan standar syarat-syarat peserta tarbiyah. Jika memenuhi syarat maka ia akan diarahkan untuk mengikuti halaqoh tarbiyah.

Lebih lanjut Rahmat menjelaskan dalam proses rekrutmen jama' $i$ ini dilakukan secara kolektif dengan menggunakan cara formal maunpun informal, rekrutmen jenis ini memiliki beberapa pola:

a. Rekrutmen ke-partai-an, yakni rekrutmen terhadap anggota masyarakat melalui kegiatan formal partai untuk menjadi anggota dan simpatisan partai. Kegiatan ini dilakukan melalui: Pertama, Training Orientasi Partai I (TOP I). Dari TOP I akan dihasilkan beberapa tingkatan calon kader, antara lain: yang memiliki kualifikasi tertinggi akan menjadi calon peserta Halaqoh Tarbiyah, yang disebut anggota pemula terbina. Kelompok inilah yang akan dibina dengan intensif di "kawah candradimuka" yang disebut halaqoh tarbiyah, seperti yang ditempuh LDK. Kualifikasi kedua akan menjadi calon anggota pemula terdaftar yang hanya boleh mengikuti Training Rutin Partai (TRP). Sedangkan kualifikasi terendah akan menjadi calon anggota partai yang hanya menerima KTA, yang berfungsi menambah dukungan dan suara bagi partai. Kedua, Training Orientasi Partai II (TOP II). TOP II berfungsi meningkatkan peserta TRP dan yang menerima KTA untuk bisa menjadi anggota pemula terbina atau peserta halaqoh tarbiyah level pemula.

Jurnal TAPIs Vol. 14 No.02 Juli-Desember 2018 
Triono,dkk: MILITANSI KADER PKS DALAM.......

b. Rekrutmen melalui pendaftaran peserta. Pendaftaran peserta ini bisa dilakukan di sekretariat tingkat pusat, wilayah, daerah, cabang hingga DPRa, di rumah-rumah kader PKS, SMS atau melalui website. Para peserta yang mendaftar juga akan ditraining melalui TOP I, TOP II dan diupayakan bisa mengikuti tarbiyah level pemula.

c. Rekrutmen melalui Lembaga Dakwah Sekolah dan Lembaga Dakwah Kampus. Hasil dari rekutmen ini juga diarahkan untuk mengikuti kegiatan tarbiyah anggota pemula.

d. Rekrutmen juga bisa dilakukan melalui berbagai kegiatan yang lain, seperti majelis ta'lim, studi intensif, kegiatan ramadhan, pelatihan, baksos, santunan dan kegiatan-kegiatan yang lain. ${ }^{21}$

Semua jenis rekrutmen ini menurut Rahmat berorientasi menjadi pintu masuk bagi calon kader untuk menjadi peserta tarbiyah level pemula. Pengkaderan formal politik dilakukan secara resmi oleh kepengurusan partai dari Dewan Pengurus Ranting (DPRa) hingga Dewan Pengurus Pusat (DPP). Pengkaderan formal sebagai organisasi induk ini terdiri dari tujuh jenjang, yakni: TOP I (Training Orientasi Partai Satu), dan TOP II. TD I (Training Dasar Satu), dan TD II.Serta TL I (Training Lanjutan Satu), dan TL II dilanjutkan dengan Training Managemen dan Kepemimpinan Sosial (TKMS). ${ }^{22}$

Tahapan selanjutnya adalah berupa pelatihan-pelatihan untuk kader yang dikeluarkan dari tingkat cabang sampai pada pusat seperti Training For Trainer(TFT) sebagai training untuk murabbi pada tingkat tinggi dan bertujuan untuk meningkatkan kualitas kader. Pengkaderan formal ini merupakan sarana pembinaan kader sekaligus penjenjangan bagi mereka yang akan

\footnotetext{
${ }^{21}$ Ibid.

${ }^{22}$ Ibid. h. 239.
}

Jurnal TAPIs Vol. 14 No.02 Juli-Desember 2018 
berimplikasi pada distribusi peran dan posisi struktural di PKS baik di internal maupun menjadi pejabat publik nantinya.Pengkaderan lainnya, yakni pada organisasi-organisasi underbow PKS dengan mengembangkan pola dan model pengkaderan sendiri-sendiri, misalnya Kesatuan Aksi Mahasiswa Muslim Indonesia (KAMMI), yang disebut dengan Daurah Marhalah (DM) I, DM II dan DM III. Pada organisasi ROHIS dikenal dengan nama Latihan Dasar Kepemimpinan (LDK), sedangkan pada LDK terdapat pembinaan yang bernama kajian rutin (mentoring).

Secara umum, penulis melihat proses penambahan kaderkader PKS dilakukan melalui pembinaan tarbiyah berbasis kelompok kecil (usroh/halaqoh) dibawah bimbingan seorang murabbi lebih sering dilakukan sebagai kegiatan non-formal partai dan dijalankan oleh para kader PKS melalui jaringan tarbiyah yang pada umumnya berbasis di kampus dan sekolah. Akan tetapi, seiring berkembangnya dakwah kemasyarakat, pembinaan seperti ini juga berjalan dikalangan masyarakat umum, khususnya kaum ibu-ibu PKS melalui Salimah dan Pos Wanita Keadilan (PWK).

\section{Militansi Kader PKS dalam Pemenangan Politik}

Sebagai partai kader, PKS memiliki sistem kaderisasi kepartaian yang sistematis dan metodik. Kaderisasi ini memiliki fungsi rekrutmen calon anggota dan fungsi pembinaan untuk seluruh anggota, kader, dan fungsionaris partai. Fungsi-fungsi ini dijalankan secara terbuka melalui infrastruktur kelembagaan partai yang tersebar dari tingkat pusat hingga tingkat ranting. Fungsionalisasi berjalan sepanjang waktu selaras dengan tujuan dan sasaran umum partai, khususnya dalam bidang penyiapan sumber daya manusia dalam partai.

Jurnal TAPIs Vol. 14 No.02 Juli-Desember 2018 


\section{Triono,dkk: MILITANSI KADER PKS DALAM.......}

Pembinaan kader bagi PKS merupakah hal yang mendasar sebab pembinaan pribadi merupakan langkah awal bagi pembinaan keluarga, masyarakat, dan bahkan negara. Dalam pandangan PKS, Islamisasi negara hanya bisa diwujudkan apabila terdapat pribadi-pribadi yang saleh, yang akan membentuk keluarga yang Islami. Selanjutnya, keluarga-keluarga itulah yang akan membentuk masyarakat yang Islami. Individu merupakan alat masyarakat dan negara yang terpenting dalam melaksanakan tugas sosial politik demi membangun negara yang Islami.

Mengenai militansi ini ada kesesuaian antara teoriseperti yang diungkapkan oleh Aay ${ }^{23}$ dengan temuan di lapangan, bahwa PKSsebagai partai kader memiliki sistem kaderisasi kepartaian yang bersifat sistematis dan metodik, kaderisasi tersebut memiliki fungsi rekrutmen calon anggota dan fungsi pembinaan untuk seluruh anggota, kader serta fungsionaris partai. Fungsi-fungsi tersebut dijalankan secara terbuka melalui infrastruktur kelembagaan partai yang tersebar dari tingkat pusat hingga tingkat ranting.

Fungsionalisasi partai berjalan sepanjang waktu selaras dengan tujuan dan sasaran umum partai, khususnya dalam penyiapan sumber daya manusia dalam partai.Pembinaan kader di tubuh PKSmerupakan hal yang mendasar dan urgen sebab pembinaan pribadi kader merupakan langkah awal bagi pembinaan keluarga, masyarakat bahkan negara. Dalam pandangan PKS, Islamisasi negara hanya bisa diwujudkan apabila terdapat pribadi-pribadi yang saleh, yang nantinya akan membentuk keluarga yang Islami. Selanjutnya keluarga-keluarga itulah yang akan membentuk masyarakat yang Islami. Individu merupakan alat masyarakat dan negara terpenting dalam

${ }^{23}$ Aay Muhammad Furqon, Partai Keadilan Sejahtera: Ideologidan Praksis Politik Kaum Muda Muslimin Kontemporer, (Jakarta: Teraju, 2004).

Jurnal TAPIs Vol. 14 No.02 Juli-Desember 2018 


\section{Triono,dkk: MILITANSI KADER PKS DALAM.......}

melaksanakan tugas sosial politik demi membangun negara yang Islami.

Pengamat politik dari Universitas Lampung menjelaskan terkait dengan militansi kader PKS ini, menurutnya yang membedakan PKS dengan partai-partai lain adalah pada sistem kaderisasinya, PKS dalam hal ini lebih baik jika dibandingkan dengan partai-partai lain. ${ }^{24}$ Nilai-nilai kaderisasi ini benar-benar dibuktikan oleh kader-kader PKS dengan siap sedia setiap ada taklimat dari qiyadah-qiyadah PKS. Dalam rangka merebut hati dari masyarakat setiap partai politik diharuskan untuk bekerja semaksimal mungkin untuk memanfaatkan kekuatan-kekuatan yang mereka miliki tidak terkecuali PKS yang memberdayakan kader-kadernya dalam kegiatan-kegiatan sosial maupun politik.

Hal ini juga di amini oleh A. Junaidi Auly ${ }^{25}$ yang menyatakan bahwa sebagai salah satu partai kader di Indonesia, loyalitas dan militansi kader PKS tidak perlu di ragukan lagi, bahkan loyalitas dan militansi kader inilah yang selama ini menjadi kekuatan inti PKS. Kerja-kerja kader PKS selama ini dilakukan karena tujuan utama untuk dakwah lillahita'ala dan mewujudkan masyarakat Indonesia yang adil dan sejahtera.

Setelah proses pembinaan diri kader, maka langkah selanjutnya adalah dengan melakukan pembinaan keluarga, ini juga sangat penting dan saling berhubungan sebab dengan membentuk pribadi yang bersih dan shaleh menjadikan kunci dalam membentuk keluarga yang shaleh, dan dari keluarga shaleh yang terbentuk inilah yang akan membentuk masyarakat yang Islami. Selain sistem kaderisasi, ideologi partai juga merupakan

\footnotetext{
${ }^{24}$ Wawancara dengan Hertanto (Akademisi/Pengamat Politik Universitas Lampung, 30 Agustus 2017, di UNILA Bandarlampung).

${ }^{25}$ Wawancara dengan A. Junaidi Auly (Anggota DPRD Lampung Periode 2009-2014, 26 September 2017, di Hotel The Ritz-Carlton Jakarta).
}

Jurnal TAPIs Vol. 14 No.02 Juli-Desember 2018 


\section{Triono,dkk: MILITANSI KADER PKS DALAM.......}

salah satu faktor yang menjadikan kader PKS loyal dan militan terhadap perjuangan partai. Ideologi Islam yang dianut PKS dapat menjadi pilar-pilar dan dasar perjuangan para kader PKS.

Gambaran mengenai militansi kader PKS yang dinilai masyarakatsejauh ini yang terlihat adalah pada saat melakukan aksi-aksi sosial tentang isu-isu publik dan keummatan, peserta yang hadir dapat mencapai ribuan massa. Menurut Triono ${ }^{26}$ penanaman nilai-nilai militansi kader PKS ini dilakukan dalam 4 hal:Pertama,pada ta'lim yang rutin dilakukan, baik itu dari DPP (Dewan Pengurus Pusat) maupun Dewan Syuro sampai pada tingkat Ranting, selain menekankan keikhlasan pada kader, karena dalam berpartai merupakan salah satu bentuk ibadah, memberi kontribusi pada partai, dalam bentuk calon legislatif (caleg), mengabdi pada masyarakat. Hal ini juga diterapkan pada penentuan caleg, agar tidak adanya rebutan mendaftar, tidak ada yang mempromosikan diri, berebut nomor urutan, harus mengeluarkan dana tapi berupa amanah dari partai yang tidak bisa ditolak juga (sistem penugasan), karena juga berupa pengorbanan tetapi karena merupakan penugasan, bukan hasrat pribadi kader.

Kedua, Pembinaan yang berkesinambungan melalui keluarga, dengan menyelesaikan masalah bersama, mencari solusi bersama serta menjalin kebersamaan, sehingga timbul ketertarikan antara sesama. Hal ini yang menguatkan para kader. Ketiga, penamaman kesadaran, keyakinan dan semangat, dengan partai adalah beribadah kepada Allah SWT, tidak memisahkan ibadah dan berpolitik. Dan keempat, yaitu penanaman nilai pengorbanan, dalam hal pengorbanan ini, ditetapkan bukan

\footnotetext{
${ }^{26}$ Triono. Strategi Political Marketing Partai Keadilan Sejahtera (PKS) Dalam Pemilu Legislatif 2014 di Provinsi Lampung, (Bandarlampung: Jurnal TAPIs Vol. 14 No. 01 Januari-Juni 2018). h. 100.
}

Jurnal TAPIs Vol. 14 No.02 Juli-Desember 2018 


\section{Triono,dkk: MILITANSI KADER PKS DALAM.......}

menikmati hasil pengorbanan orang lain bahkan menikmati dengan mengorbankan orang lain seperti korupsi.

Menurut Ade Utami Ibnu, ${ }^{27}$ konsep pemimpin yang ikhlas dan kader yang taat kepada pimpinan itu menjadi modal lahirnya militansi kader PKS. Dan karena itulah sistem di PKS berjalan dan ketika ada anggota yang memiliki wawasan yang sangat luas, itu tidak kemudian membuat "loh, kan pinteran saya dari pada pimpinan itu" tidak, tidak begitu. Justru dengan wawasan yang baik itu, kader-kader PKS bisa berkontribusi terhadap partai ini, terhadap pimpinannya dan memberikan masukan-masukan yang sangat baik, kepada pimpinannya. Dan itu yang membuat kebijakan-kebijakan di partai ini komprehensif melihatnya, karena bukan hasil pandangan-pandangan pribadi.

Ade menambahkan bahwa militansi kader disamping melalui pembinaan kader juga pemimpin struktural partai yang mengedepankan musyawarah dalam setiap pengambilan kebijakan partai. Dari sini kemudian ketaatan kader ini sangat percaya bahwa semua hasil kebijakan-kebijakan yang diambilnya melalui mekanisme syuro, bukan kepentingan-kepentingan pribadi, bukan kepentingan politik melainkan untuk kepentingan bangsa dan negara serta masyarakat. Wajar kemudian masyarakat melihat begitu keputusan sudah diambil oleh PKS, kader-kader PKS akan memegang prinsip sami'na wa atha'na.

Arief Munandar ${ }^{28}$ dalam disertasinya menjelaskan tentang fenomena ini. Menurut hasil kajiannya PKS menggunakan modus

\footnotetext{
${ }^{27}$ Wawancara dengan Ade Utami Ibnu (Pengurus DPW PKS Lampung/Anggota DPRD Lampung Periode 2014-2019, 26 Juli 2017, di Kantor DPW PKS Lampung).

${ }^{28}$ Arief Munandar, Antara Jemaah dan Partai Politik: Dinamika Habitus Kader Partai Keadilan Sejahtera (PKS) Dalam Arena Politik Indonesia Pasca Pemilu 2004,Disertasi Doktor Ilmu Politik Universitas

Jurnal TAPIs Vol. 14 No.02 Juli-Desember 2018 
Triono,dkk: MILITANSI KADER PKS DALAM.......

operandi Jamaah Tarbiyah untuk memperbesar peluang mendapatkan kader baru. PKS menggunakan dua strategi dalam merekrut kader baru, yang pertama ialah pola rektrutmen individual (al-da'wah al fardhiyyah), yaitu pendekatan orang perorang atau komuniasi secara langsung. Calon kader ini akan direkrut dan diajak berpartisipasi dalam serangkaian forum keagamaan dan kepelatihan yang diorganisir oleh PKS seperti usrah (keluarga) atau halaqah (kelompok studi terbatas) atau liqa (pertemuan mingguan), rihlah (rekreasi), mukhayyam (camping), daurah (pelatihan intelektual dan workshop Islami), nadwah (seminar), dan seterusnya. Pertemuan ini dilakukan secara rutin dengan harapan para peserta calon kader memiliki pemahaman yang sama.

Kedua adalah pola rekrutmen institusional (al da'wahal'amma), ada pelbagai bentuk rekrutmen institusional yang bisa melibatkan struktur formal PKS maupun organisasi-organisasi sayap yang berafiliasi dengan PKS dengan bekerja sama dengan institusiinstitusi keagamaan seperti masjid maupun institusi pendidikan seperti sekolah dan universitas.Karakteristik militansi kader-kader PKS dalam perjuangan membesarkan dan memenangkan PKS dapat dilihat dari empat faktor utama: (1) Kemampuan kader dalam manajemen organisasi. (2) Kemampuan kader dalam strategi komunikasi massa. (3) Kemampuan kader dalam memahami nilai perjuangan PKS. (4) Kemampuan kader dalam kerja jama'i.

Dari pemaparan di atas dapat diketahui dinamika perolehan suara PKS yang fluktuatif dan menunjukkan grafik kenaikan suara dalam setiap pemilu memberikan gambaran bahwa faktor militansi yang kuat dan jiwa soliditas yang dimiliki oleh

Indonesia, (Jakarta: Program Pascasarjana FISIP Universitas Indonesia, 2004). h. 101-102.

Jurnal TAPIs Vol. 14 No.02 Juli-Desember 2018 
Triono,dkk: MILITANSI KADER PKS DALAM.......

kader-kader PKS merupakan output dari sistem kaderisasi dan proses tarbiyah yang dimiliki oleh partai PKS itu sendiri. Militansi kader ini menjadi kekuatan utama dalam menggerakan mesin PKS dalam kerja-kerja politik untuk meraih kemenangan politik dalam pemilu legislatif 2009 dan 2014 di Provinsi Lampung.

\section{Penutup}

Sebagai partai yang berasaskan Islam dan partai dakwah, PKS dipandang sebagai partai yang memiliki sistem kepartaian yang kokoh dan kader-kader yang solid. Soliditas ini hendaknya dibarengi dengan konsepsi karakteristik yang rahmatan lil alamin. Masyarakat masih menilai soliditas PKS berlaku untuk internal PKS dengan identitas yang berbeda dengan masyarakat dan kelompok lainnya. Stigma eksklusif pada PKS dan kadernya masih menjadi pekerjaan rumah yang harus segera diselesaikan. Lemahnya komunikasi dan kualitas hubungan dengan pihak lain menjadikan kurangnya rasa simpati dari masyarakat kepada PKS. Diperlukan upaya-upaya nyata dari struktur partai dan kaderkader PKS dalam memperbaiki stigma eksklusivitas ini dengan membangun komunikasi dan ukhuwwah dengan kelompokkelompok muslim lainnya. Pola hubungan sosial kader-kader PKS dengan masyarakat lainnya kiranya perlu diperbaiki dengan senantiasa lebih terbuka terhadap perbedaan yang ada, serta bersikap bijak dengan menjalin silaturrahim dengan kelompokkelompok harakah Islam yang lain.

Eksistensi PKS di Lampung terlihat dengan tidak bergantungnya kader-kader pada figuritas atau ketokohan baik ditingkat nasional maupun di tingkat lokal. Dalam upaya mencapai kemenangan-kemenangan politik pada kontestasi pemilu, kedepan PKS perlu menggalang jaringan mitra dan relawan politik sebagai langkahstrategisdalam melakukan 


\section{Triono,dkk: MILITANSI KADER PKS DALAM.......}

ekspansi politik diluar kekuatan internal PKS. Hal mendasar yang perlu diperbaiki adalah pola komunikasi kader-kader PKS di tingkat sosial masyarakat agar lebih terbuka dan menerima perbedaan dengan kelompok dan fikrah gerakan Islam lainnya. Budaya politik di PKS seperti halnya rakorwil dan pemilu raya hendaknya tetap dilestarikan sebagai bagian dalam proses demokratisasi di internal PKS. Pelibatan kader-kader dalam proses pengambilan kebijakan dan perumusan produk-produk politik akan memberikan efek pada kader dengan munculnya rasa memiliki dan rasa sepenanggungan dalam proses kerja-kerja politik untuk mencapai tujuan-tujuan politik.

\section{Daftar Pustaka}

Amal,Ichlasul,TeoriteoriMutahirPartaiPolitik, Yogyakarta:PTTiar a Wacana, 2007.

Amir, Zainal Abdidin, Peta Politik Islam Pasca Soeharto, Jakarta: LP3ES, 2003.

Andrianus,Toni Pito, dkk., Mengenal Teori-Teori Politik dari Sistem Politik sampai Korupsi, Bandung: Penerbit Nusantara, 2006.

Damanik, Ali Said, Fenomena Partai Keadilan; Transformasi 20 Tahun Gerakan Tarbiyah di Indonesia, Jakarta: Teraju, 2002.

Easton,David, A Framework for Political Analysis, Toronto: The Prentice Hall of Canada, 1965.

Furqon,Aay Muhammad, Partai Keadilan Sejahtera: Ideologi dan Praksis Politik Kaum Muda Muslimin Kontemporer, Jakarta: Teraju, 2004.

Herdiansah, Ari Ganjar, Rasionalitas PKS; Berdemokrasi ala Tarbiyah, Bandung: Unpad Press, 2016.

Jurnal TAPIs Vol. 14 No.02 Juli-Desember 2018 


\section{Triono,dkk: MILITANSI KADER PKS DALAM.......}

Husein,Harun, Pemilu Indonesia: Fakta, Angka, Analisis, dan Studi Banding, Jakarta: $\quad$ Perludem, 2014.

Marsh, David,dan Stoker, Gerry,Teori dan Metode dalam Ilmu Politik, Bandung: Nusa Media, 2011.

Miles, M. B, \& Huberman, A. M, Qualitative Data Analysis, A Sourcebook of New Methods, London, New Delhi: Sage Publications, Beverly Hills, 1992.

Munandar,Arief, Antara Jemaah dan Partai Politik: Dinamika Habitus Kader Partai Keadilan Sejahtera (PKS) Dalam Arena Politik Indonesia Pasca Pemilu 2004,

Disertasi Doktor Ilmu Politik Universitas Indonesia, Jakarta: Program Pascasarjana FISIP Universitas Indonesia, 2004.

Rahmat,M. Imdadun, Ideologi Politik PKS; Dari Masjid Kampus ke Gedung Parlemen, $\quad$ Yogyakarta: LkiS, 2008.

Ridha,Abu, Politik Tegak Lurus PKS; Jalan Mencapai Kemenangan yang Bermartabat dan Penuh Berkah, Solo: Era Adicitra Intermedia, 2018.

Tarbiyah di Indonesia, Jakarta: Teraju, 2002.

Triono. Strategi Political Marketing Partai Keadilan Sejahtera (PKS) Dalam Pemilu Legislatif 2014 di Provinsi Lampung, Bandarlampung: Jurnal TAPIs Vol. 14 No.

01 Januari-Juni 2018. h. 100.

www.hidayah.com/pks siap[27/7/2017]. 